\title{
COPPER, NICKEL AND ZINC PHYTOAVAILABILITY IN AN OXISOL AMENDED WITH SEWAGE SLUDGE AND LIMING
}

\author{
Adão Luiz Castanheiro Martins ${ }^{1}$; Ondino Cleante Bataglia2*; Otávio Antonio de Camargo ${ }^{2}$ \\ ${ }^{I}$ Prefeitura do Municipio de São Paulo - Secretaria Municipal de Abastecimento, Av. Zaki Narchi, 600 - \\ 02029-000 - São Paulo, SP - Brasil. \\ ${ }^{2}$ IAC - Centro de Pesquisa e Desenvolvimento de Solos e Recursos Ambientais, C.P. 28 - 13001-970 - Campinas, \\ SP - Brasil. \\ *Corresponding author <ondino@iac.sp.gov.br>
}

\begin{abstract}
Contents of heavy metal on agricultural soils have been raised by land applications of sewage sludge and may constitute a hazard to plants, animals and humans. A field experiment was carried out from 1983 to 1987, to evaluate the long-term effect of sewage sludge application, with and without liming, on heavy metal accumulation and availability in a Rhodic Hapludox soil grown with maize (HMD 7974 hybrid). Trials were set up in a completely randomized blocks design with four replications. Each block was split in two bands, one with and another without liming. The sludge was applied in each band at rates: 0, 20, 40, 60 and $80 \mathrm{Mg} \mathrm{ha}^{-1}$ (dry basis) in a single application; and 40, 60 and $80 \mathrm{Mg} \mathrm{ha}^{-1}$ split in two, three and four equal yearly applications, respectively. The soil was sampled for chemical analysis each year after harvest. Soil samples were analysed for $\mathrm{Cu}, \mathrm{Ni}$ and $\mathrm{Zn}$ in extracts obtained with DTPA and Mehlich-3 solutions, and in extracts obtained by digestion with nitric-perchloric acid (total metal contents), using an inductively coupled plasma (ICP) spectrometer. In general, $\mathrm{Zn}, \mathrm{Cu}$ and $\mathrm{Ni}$ concentrations in DTPA and Mehlich-3 extracts increased linearly with sludge application. Total $\mathrm{Cu}$ and $\mathrm{Zn}$ concentrations increased when sludge was applied, whereas total $\mathrm{Ni}$ concentrations were not affected. Both extractants were suitable to evaluate $\mathrm{Cu}$ and $\mathrm{Zn}$ availability to corn in the soil treated with sewage sludge. Liming reduced the DTPA extractability of Zn. DTPA-extractable $\mathrm{Cu}$ concentrations were not significantly affected by liming. Mehlich-3-extractable $\mathrm{Cu}$ and $\mathrm{Zn}$ concentrations increased with liming. Only DTPA extractant indicated reduction of Ni concentrations in the soil after liming. Key words: DTPA, Mehlich-3, heavy metals, extractability, corn
\end{abstract}

\section{FITODISPONIBILIDADE DE COBRE, NÍQUEL E ZINCO EM UM LATOSSOLO VERMELHO TRATADO COM LODO DE ESGOTO E CALAGEM}

\begin{abstract}
RESUMO: A reciclagem agrícola do lodo de esgoto tem provocado o acúmulo de metais pesados no solo e na água, podendo atingir níveis tóxicos e causar danos às plantas cultivadas, aos animais e ao homem, por meio da cadeia trófica. Foi desenvolvido um experimento, em condições de campo entre 1983 e 1987, onde foram avaliados os efeitos da aplicação de lodo de esgoto por quatro anos, com e sem calagem, sobre a acumulação e disponibilidade de metais pesados em um Latossolo Vermelho distrófico típico cultivado com milho (HMD 7974). O delineamento utilizado foi o de blocos completos ao acaso, com quatro repetições. Cada bloco foi dividido em duas faixas nas quais foram aplicados os tratamentos com e sem calcário, e em cada faixa foi aplicado o lodo nas seguintes doses: $0,20,40,60$ e $80 \mathrm{Mg} \mathrm{ha}^{-1}$ (material seco) de lodo de esgoto, em aplicação única; e as doses de 40,60 e $80 \mathrm{Mg} \mathrm{ha}^{-1}$, parceladas em dois, três e quatro anos, respectivamente. A fitodisponibilidade dos metais foi avaliada pelos extratores DTPA e Mehlich-3. Os teores extraíveis de $\mathrm{Cu}$, $\mathrm{Ni}$ e $\mathrm{Zn}$ no solo aumentaram linearmente com as doses de lodo de esgoto, para os dois extratores usados. A adição de lodo de esgoto elevou os teores totais de $\mathrm{Cu}$ e $\mathrm{Zn}$, mas não afetou os teores de Ni no solo. Os extratores DTPA e Mehlich-3 foram igualmente eficientes na predição da fitodisponibilidade de $\mathrm{Cu}$ e $\mathrm{Zn}$. A adição de calcário reduziu a extratabilidade de Zn-DTPA, não alterou a de Cu-DTPA e aumentou os teores de $\mathrm{Cu}$ e Zn extraíveis do solo por Mehlich-3. Somente o extrator DTPA mostrou a redução do teor de Ni extraível do solo com a adição de calcário.

Palavras-chave: DTPA, Mehlich-3, metais pesados, extratibilidade, milho
\end{abstract}

\section{INTRODUCTION}

Recicling sewage sludge in agriculture has resulted in accumulation of heavy metals in soils, specially $\mathrm{Cd}, \mathrm{Cr}, \mathrm{Cu}, \mathrm{Ni}$ and $\mathrm{Zn}$, and mainly when the residue is originated from industrial areas (Williams et al., 1980; Chang et al., 1984; Krebs et al., 1998). This practice polutes the soil and water resources and causes toxicity to crops, animals and humans through the trophic chain (Logan \& Chaney, 1983; McBride, 1995). The extension 
of the damage resulting from the presence of heavy metals will depend, among other factors, on the quantities of sewage sludge added to the soil and to the chemical forms in which they will occur (Chaney \& Giordano, 1977; Latterel et al., 1978; Anjo \& Mattiazzo, 2001).

Several factors control the availability of soil metals to the plants. Even though high quantities of heavy metals are added to soils by application of sewage sludge, the absorption of such metals by plants represent less than $1.0 \%$ of the total introduced by the residue input (Chang et al., 1984).

Heavy metals may adsorb strongly to the soil organic and mineral coloids like clay, iron hydroxides and manganese oxides, form insoluble inorganic compounds with hydroxides, carbonates and sulfides, and form complex molecules with soil organic matter (Chaney \& Giordano, 1977). Metals applied to the soil in the form of salts are more available to plants and more extractable by the DTPA extractant than metals applied in equivalent quantities by sewage sludge (Dowdy \& Larson, 1975; Korcak \& Fanning, 1985). Liming-induced higher $\mathrm{pH}$ may reduce the heavy metal availability because of the formation of less soluble oxides and carbonates (Heckman et al., 1987; Berton et al., 1997).

The control of the soil availability of heavy metals to safe levels for humans, animals, plants and environment, mainly after a long period of sludge application in a specific soil, is still a matter of concern among scientists. During the initial period of application, the sewage sludge organic matter not only strongly protects the plant from metal acquisition, but also improves soil properties and provides a greater control on metal solubility (McBride, 1995). These benefits are usually reduced along time with the mineralization of the sludge organic fraction. Neverthless, McGrath \& Cegarra (1992) observed that 20 years after the application of sludge in a soil, when $70 \%$ of the organic matter was already decomposed, a relatively constant percentage of metals $(\mathrm{Cd}, \mathrm{Cr}$, $\mathrm{Ni}, \mathrm{Pb}$ and $\mathrm{Zn}$ ) extracted from soil fractions was found. Other authors have reported a decrease on metal availability with time (Bidwell \& Dowdy, 1987).

Several extractant solutions have been tested to evaluate the phytoavailability of heavy metals in soil samples from field experiments using sewage sludge (Simonete \& Kiehl, 2002). Korcak \& Fanning (1978) found correlations between the amounts of $\mathrm{Cd}, \mathrm{Cu}, \mathrm{Ni}$ and $\mathrm{Zn}$ extracted by DTPA and Mehlich-1 $\left(0.05 \mathrm{~mol} \mathrm{~L}^{-1} \mathrm{HCl}\right.$ $+0.0125 \mathrm{~mol} \mathrm{~L}^{-1} \mathrm{H}_{2} \mathrm{SO}_{4}$ ) and the amounts absorbed by maize plants. Berton et al. (1997), using maize as test plant, observed that DTPA predict with efficacy the availability of $\mathrm{Cu}$ and $\mathrm{Zn}$, but did not to predict Ni. None of the extractants used by Haq et al. (1980) - aqua regia, DTPA, NTDA, EDTA, acetic acid, ammonium acetate, hydrochloric acid and aluminum chloride - was adequate to evaluate $\mathrm{Cu}$ availability for plants of swiss chard. The extractant solutions Mehlich-1, Mehlich-3 and DTPA were not efficacious to evaluate the availability of $\mathrm{Pb}, \mathrm{Cd}$, $\mathrm{Cr}$ and $\mathrm{Ni}$ for wheat plants and of $\mathrm{Pb}$ and $\mathrm{Cd}$ for common bean plants. Correlations between soil and plant contents were obtained only for $\mathrm{Ni}$ and $\mathrm{Cr}$ when using the common bean as test plant (Abreu et al., 1995). The efficacy of the extractant solutions depends mainly on the type of soil, the element under concern and on the species used as plant test. The extractant DTPA has shown to be superior in discriminating the liming effect on the availability of soil metals (Korcak \& Fanning, 1978; Singh \& Narwal, 1984; Bataglia \& Raij, 1994).

Long term field studies under tropical or subtropical conditions to evaluate the effects of sewage sludge on the accumulation and availability of heavy metals in soils are scarce in the literature. The present research aimed at studying the effects of sewage sludge application, in a long-term field experiment, on the accumulation of heavy metals $(\mathrm{Cu}, \mathrm{Zn}$ and $\mathrm{Ni})$ in the soil and their availability to maize plants, with and without liming.

\section{MATERIAL AND METHODS}

Field experiments were carried out in Cordeirópolis, SP, Brazil $\left(22^{\circ} 32^{\prime} \mathrm{S}, 4^{\circ} 27^{\prime} \mathrm{W}, 639 \mathrm{~m}\right.$ altitude). Sewage sludge was applied to a Rhodic Hapludox soil cultivated with maize (HMD 7974 hybrid), from 1983 to 1987 . The chemical analyses (Raij \& Quaggio, 1983) of soil samples taken from the $0-20 \mathrm{~cm}$ layer, indicates the follow ing results: $\mathrm{pH} \quad\left(\mathrm{CaCl}_{2}\right)-3,9$; organic matter $48 \mathrm{~g} \mathrm{~kg}^{-1}$; P-resin: $5 \mathrm{mg} \mathrm{dm}{ }^{-3} ; \mathrm{K}^{+}, \mathrm{Ca}^{2+}, \mathrm{Mg}^{2+}$ and $\mathrm{H}^{+}+\mathrm{Al}^{3+}: 1.6 ; 3.0 ; 1.0$; and $97 \mathrm{mmol}_{\mathrm{c}} \mathrm{dm}^{-3}$ of soil, respectively. The physical analyses of the soil samples (Camargo et al., 1986) indicated: coarse sand - 75; fine sand -200 ; silt - 145; and clay - $580 \mathrm{~g} \mathrm{~kg}^{-1}$ soil, respectively.

Sewage sludge anaerobically digested and not treated with calcium monoxide and ferric chloride, was sampled in São Paulo, during 1983 to 1986 . The sludge was chemically characterized yearly (Table 1) and the analysis followed the procedure: $1.000 \mathrm{~g}$ samples were digested with $50 \mathrm{~mL}$ of $4 \mathrm{~mol} \mathrm{~L}^{-1} \mathrm{HNO}_{3}$ solution, at $180^{\circ} \mathrm{C}$, for one hour; the digested samples stood at room temperature and after that, the volume was adjusted to $50 \mathrm{~mL}$ with deionized water and filtered through filter paper. The filtered digested solutions were analysed for $\mathrm{K}$ by flame photometry; $\mathrm{P}$ by the vanado-molybdate spectrophotometric method; $\mathrm{Ca}, \mathrm{Mg}, \mathrm{Fe}, \mathrm{Cu}, \mathrm{Ni}, \mathrm{Mn}$, and $\mathrm{Zn}$, by atomic absorption spectrophotometry.

The total $\mathrm{N}$ concentration in sludges was determined by the micro-Kjeldhal method and the total $\mathrm{C}$ by the oxidation of organic matter using $0.17 \mathrm{~mol} \mathrm{~L}^{-1}$ potassium dichromate solution and titration of the excess bichromate with a $0.5 \mathrm{~mol} \mathrm{~L}^{-1}$ ammonium ferrous sulfate solution, using diphenylamine as indicator (Raij \& Quaggio, 1983). Cd and $\mathrm{Pb}$ were also determined by 
atomic absorption spectrofotometry, but their total contents were below the detection limit $\left(<0.01 \mathrm{mg} \mathrm{kg}^{-1}\right)$.

Trials were set up in a totally randomized, complete blocks design $(n=4)$. Each block was split in two bands, one with and another without liming. The sludge was applied in each band at rates: $0,20,40,60$ and 80 $\mathrm{Mg} \mathrm{ha}^{-1}$ (dry basis) in a single application; and 40, 60 and $80 \mathrm{Mg} \mathrm{ha}^{-1}$ split in two, three and four equal yearly applications, respectively. Each experimental unit consisted of $42-\mathrm{m}^{2}$ plots, with six rows (7 m length, $1 \mathrm{~m}$ spacing) cultivated with maize, the central rows used at harvest $\left(10 \mathrm{~m}^{2}\right)$ for plant yield evaluations.

The sewage sludge was applied by hand and incorporated into the soil in the $15 \mathrm{~cm}$ depth layer, during October, 1983. The plots corresponding to the split doses of sludge, received new applications in October 1984, 1985 and 1986. The band of each plot treated with lime, received two applications of 6.0 and $3.5 \mathrm{Mg} \mathrm{ha}^{-1}$ calcinated lime $(43.8 \% \mathrm{CaO}$ e $27.2 \% \mathrm{MgO})$ to rise base saturation to $70 \%$, during October 1983 and September 1984. All plots received a P-K fertilization consisting of $100 \mathrm{~kg} \mathrm{P}_{2} \mathrm{O}_{5} \mathrm{ha}^{-1}$ as simple superphosphate and $60 \mathrm{~kg} \mathrm{~K} \mathrm{~K}_{2}$ $\mathrm{ha}^{-1}$ as potassium chloride, applied to rows before sowing.

Soil samples (ten subsamples) were taken during the four planting years from each treated plot after harvest. Soil samples were analysed for $\mathrm{pH}$ $\left(\mathrm{CaCl}_{2} 0.01 \mathrm{~mol} \mathrm{~L}^{-1}\right) ; \mathrm{Cu}, \mathrm{Ni}, \mathrm{Zn}$ concentrations in extracts obtained with DTPA (Lindsay \& Norwell, 1978) and Mehlich-3 (Mehlich, 1984), and for the total metal concentrations in extracts obtained by digestion with concentrated nitric-perchloric acids (Abreu et al., 1996). Concentrations of metals were determined in all extracts using an inductively coupled plasma spectrometer (ICPOES).

Plant samples were collected in two stages: (1) at 60-65 days of age, leaves from position +4 were taken from 20 plants per plot, and the one-third mid-leaf of the limbs used for chemical analyses; (2) at harvest, four maize plants per plot (central rows) were separated into shoots (leaves + stalks) and grain. Plant samples were dried in a forced air oven at $65^{\circ} \mathrm{C}$ until constant mass for dry matter determination and ground in a Willey type grinder; $1.000 \mathrm{~g}$ samples were then incinerated at $500^{\circ} \mathrm{C}$ for two hours and extracts were obtained by suspending the ashes in $2 \mathrm{~mol} \mathrm{~L}^{-1} \mathrm{HCl}$ and filtering in filter paper
(Bataglia et al., 1978). Leaf $\mathrm{Cu}, \mathrm{Ni}$ and $\mathrm{Zn}$ concentrations were determined by atomic absorption spectrometry.

Total contents of heavy metals in maize plants were estimated from concentration and dry matter yield data of shoots and grain. The total dry matter and grain yield data was obtained at harvest, using all plants from the central rows of each plot.

The effects of sewage sludge on the extractable (DTPA, Mehlich-3) metal concentrations and on the total-metal concentrations in the soil samples were interpreted based on the polynomial regression analysis for the data obtained in the treatments correspondent to the doses 0 to $80 \mathrm{Mg} \mathrm{ha}^{-1}$ sludge in a single application at the beginning of the field experiments. The liming effects were interpreted from the analysis of variance and the efficacy of the extractants in predicting the soil availability of heavy metals for plants were evaluated by means of simple linear correlation analysis between leaf metal concentrations, plant total metal contents and extractable (DTPA, Mehlich 3) soil metal concentrations.

\section{RESULTS AND DISCUSSION}

\section{Extractability of heavy metals from soil}

Concentrations of $\mathrm{Zn}$ in DTPA and Mehlich-3 extracts increased linearly with increasing sludge doses, with or without liming (Figure 1). These results are similar to those obtained by Korcak \& Fanning (1985) and Rappaport et al. (1988) for the DTPA extractant, and by Cavallaro et al. (1993) and Oliveira \& Mattiazzo, (2001) for the Mehlich-3 extractant. The increase in the extractable soil $\mathrm{Zn}$ concentrations was proportional to the increase in the sewage sludge rates applied to the soil (Table 2). Rappaport et al. (1988) also observed this relationship between the extractable soil $\mathrm{Zn}$ concentrations and the sewage sludge rates applied to the soil.

Liming reduced the extractability of Zn-DTPA and the inverse effect was observed for Zn-Mehlich-3. Similar results were obtained by Korcak \& Fanning (1978) and Bataglia \& Raij (1994) when using DTPA. The small range of values observed for the extractable Zn soil concentrations due to liming, may in part be explained by the effect of the sludge on soil $\mathrm{pH}$ (Table 3). Although the addition of lime resulted in steady increase in soil $\mathrm{pH}$ along the years, $\mathrm{pH}$ values were only significantly higher in 1984 and 1985, but still remained below

Table 1 - Characterization of sewage sludge samples utilized in the experiment.

\begin{tabular}{|c|c|c|c|c|c|c|c|c|c|c|c|c|}
\hline Year & $\mathrm{C}$ & $\mathrm{N}$ & $\mathrm{P}$ & $\mathrm{Ca}$ & $\mathrm{Mg}$ & $\mathrm{K}$ & $\mathrm{Fe}$ & $\mathrm{Cu}$ & $\mathrm{Ni}$ & $\mathrm{Mn}$ & $\mathrm{Zn}$ & Moisture \\
\hline & $\ldots$ & $\cdots$ & -- & $\mathrm{kg}^{-1}$ & -- & -- & $\cdots$ & $\ldots$ & $\ldots m$ & $g^{-1}-$. & $\ldots$ & $\mathrm{g} \mathrm{kg}^{-1}$ \\
\hline 1983 & 217 & 14 & 8 & 24 & 9 & 4 & 38 & 791 & 322 & 315 & 1,888 & 605 \\
\hline 1984 & 265 & 16 & 2 & 15 & 6 & 2 & 44 & 975 & 401 & 423 & 2,904 & 570 \\
\hline 1985 & 261 & 16 & 2 & 20 & 7 & 3 & 41 & 1,148 & 459 & 479 & 3,326 & 610 \\
\hline 1986 & 286 & 9 & 2 & 21 & 12 & 2 & 84 & 989 & 1.240 & 223 & 4,035 & 600 \\
\hline
\end{tabular}


6.0. The unexpected increase in the Zn-Mehlich-3 extract concentrations in the limed treatments can be related to the acid characteristic of this extractant solution (acetic,

Table 2 - Quantities of $\mathrm{Cu}, \mathrm{Ni}$ and $\mathrm{Zn}$ added to the soil by the sewage sludge, in single or split applications.

\begin{tabular}{lccc}
\hline Sludge & $\mathrm{Cu}$ & $\mathrm{Ni}$ & $\mathrm{Zn}$ \\
\hline $\mathrm{Mg} \mathrm{ha}^{-1}$ & 15.8 & 6.4 & 38 \\
20 & 31.6 & 12.8 & 76 \\
40 & 47.4 & 19.2 & 114 \\
60 & 63.2 & 25.6 & 152 \\
80 & 35.3 & 14.4 & 96 \\
$40^{\mathrm{p}}$ & 58.3 & 23.6 & 163 \\
$60^{\mathrm{p}}$ & 78.1 & 48.4 & 244 \\
$80^{\mathrm{p}}$ & & $\mathrm{kg} \mathrm{ha}$ & \\
\hline
\end{tabular}

PTotal doses of 40, 60 e $80 \mathrm{Mg} \mathrm{ha}^{-1}$ split in 2, 3 and 4 years, respectively, adding $20 \mathrm{Mg} \mathrm{ha}^{-1}$ year $^{-1}$

DTPA
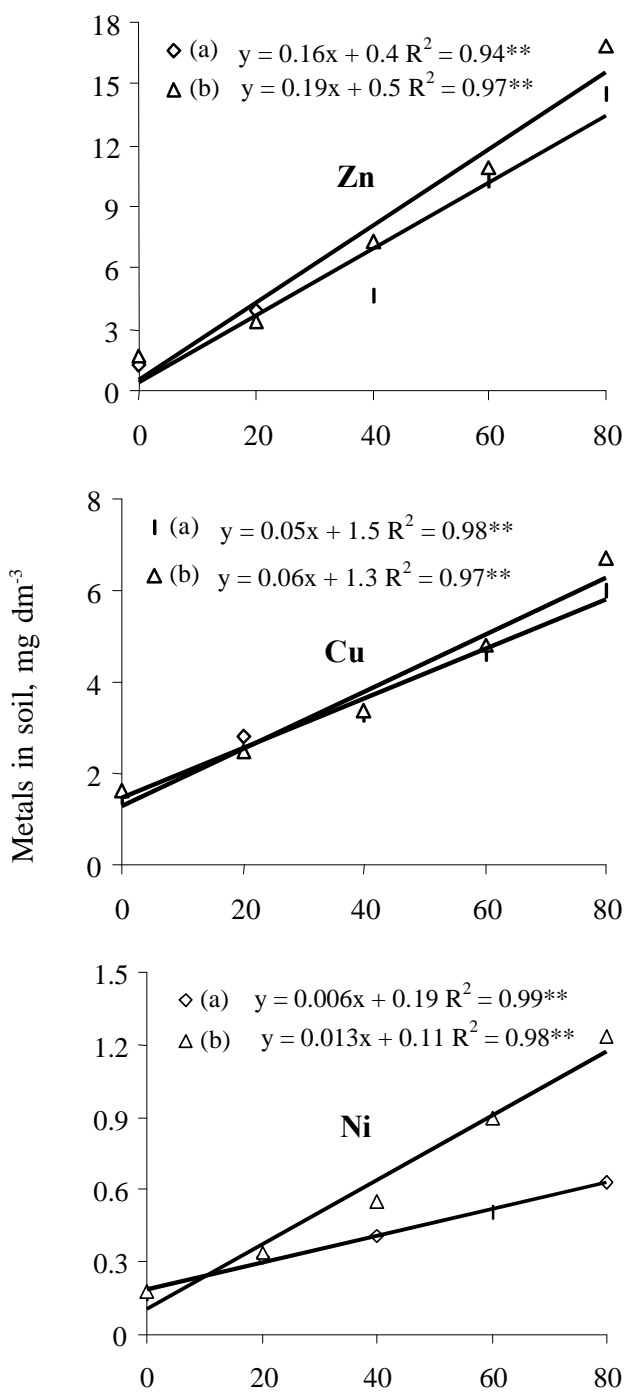

nitric and fluoridric acids + EDTA), which might be strong enough to overpass the liming effect.

Similarly, extractable $\mathrm{Cu}$ concentrations with both extractants also increased linearly with the increasing sewage sludge doses (Figure 1), corroborating the results of Korcak \& Fanning (1985) and Rappaport et al. (1988). The addition of lime did not alter the concentrations of $\mathrm{Cu}$ DTPA but induced an increase in the Cu-Mehlich-3 concentrations. Krebs et al. (1998) observed that $\mathrm{Cu}$ concentrations in soil extracts obtained with $0.1 \mathrm{~mol} \mathrm{~L}^{-1} \mathrm{NaNO}_{3}$ solution were not affected by liming, possibly because $\mathrm{Cu}$ forms stable complexes with soluble organic molecules. In such complexes, $\mathrm{Cu}$ would be protected from adsorption by soil mineral particles and, consequently, more easily extracted.

Working with 24 different types of soil (Camargo et al., 1982), observed that the DTPA extractant discriminated the variation in $\mathrm{Cu}$ concentrations re-

Mehlich-3
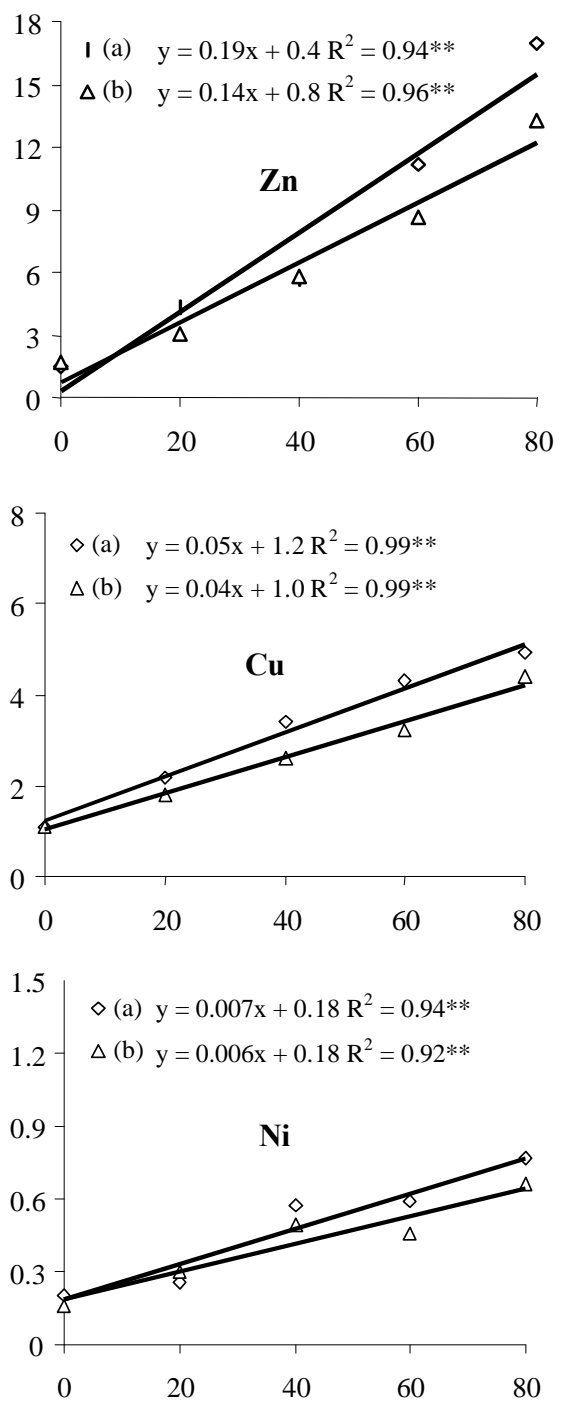

Figure 1 - Concentrations of heavy metals extracted with DTPA and Mehlich-3 solutions, from a soil treated with increasing sewage sludge doses, with (a) and without (b) liming. 
sulting from treatments with and without liming, except for three soils, two of them having high organic matter content, and the other, low $\mathrm{Cu}$ concentration $\left(<0.4 \mathrm{mg} \mathrm{dm}^{-3}\right)$. The soil and sewage sludge organic matter might play important role in the control of $\mathrm{Cu}$ availability, possibly through complexation reactions (McBride, 1989).

Several authors have demonstrated that the lower $\mathrm{Cu}$ response to $\mathrm{pH}$ changes as compared to $\mathrm{Zn}$ (Jeffery \& Uren, 1983; Sims \& Kline, 1991), might be related to the different chemical performance of these elements in the soil and in the sludge. Luo \& Christie (1998) obtained different chemical fractions (exchangeable fraction, carbonates, $\mathrm{Fe}$ and $\mathrm{Mn}$ oxides, organic and residual fractions) in two soils (sandy and claiy) before and after treatment with rural or urban sewage sludge. In the sludges, the major part of the $\mathrm{Cu}$ was associated to the organic fraction (30.4 e $54.7 \%$ ), followed by the residual fraction (12.8 e $30.7 \%)$, carbonates (7.2 e $25.5 \%)$, Fe and Mn oxides (9.3 e $1.7 \%$ ) and the exchangeable fraction (16.0 e $11.6 \%)$. The major part of the $\mathrm{Zn}$ was associated to the residual fraction (72.2 e 55.9), followed by the $\mathrm{Fe}$ and $\mathrm{Mn}$ oxides fraction (23.4 and $15.6 \%)$, organic (9.5 e $7.1 \%$ ), carbonates (1.6 e $13.6 \%$ ) and exchangeable fraction (1.1 and $0.1 \%$ ). After application of sludge, approximately $74 \%$ and $80 \%$ of the added $\mathrm{Cu}$ and $\mathrm{Zn}$ were found in the residual fraction, for both soils (Luo \& Christie, 1998). The major part of the extractable $\mathrm{Cu}$ and $\mathrm{Zn}$ was associated to the organic fraction and to the $\mathrm{Fe}$ and $\mathrm{Mn}$ oxides fraction, respectively.

Increasing sewage sludge doses induced a linear increase in the Ni concentrations of soil extracts obtained with both extractants (Figure 1). The results obtained for Ni-EDTA were similar to those obtained by Valadares et al. (1983) and were correlated to the total quantities of $\mathrm{Ni}$ added to the soil by the sludge. On the other hand, Williams et al. (1980) observed that Ni concentration in the soil was not affected by increasing rates of sewage sludge $\left(0,45,90,135,180\right.$ e $\left.225 \mathrm{Mg} \mathrm{ha}^{-1}\right)$. In this research, the analyses run in the sludge samples taken in 1985 and 1986 (Table 1) indicated that total Ni concentrations exceeded the critical limits permitted for use in agriculture, according to Norm CETESB 4230 (CETESB, 1999). Consequently, large quantities of this element were applied to the field experiment (Table 2). Although Ni concentrations increased with increasing sludge doses, values obtained for both extractants remained within the regular range for soils of the State of São Paulo (0.5 a $\left.1.4 \mathrm{mg} \mathrm{dm}^{-3}\right)$, according to Rovers et al. (1983).

Only the DTPA extractant showed reduction in the extractable $\mathrm{Ni}$ concentration of samples from limed treatments (Figure 1). In studies of Ni adsorption-desorption in the soil, Pombo et al. (1989) observed that liming- induced higher soil $\mathrm{pH}$ increased soil adsorption capacity. Both soils (Hapludox and Red Yellow Podzol) presented higher $\mathrm{Mg}$ concentrations in the extracts of $\mathrm{Ni}$ adsorption, indicating that $\mathrm{Ni}$ competes with $\mathrm{Mg}$ by the same exchange soil sites. On the other hand, the high quantities of desorbed $\mathrm{Ni}$ (with $0.01 \mathrm{~mol} \mathrm{~L}^{-1} \mathrm{HCl}$ solution) found for the Red Yellow Podzol under $\mathrm{pH}$ 5.5, rose doubts about the soil $\mathrm{pH}$ management concept to imobilize heavy metals added to soils. Camargo et al. (1989) observed also an increase in the soil capacity for Ni adsorption after liming.

The well known effect of soil reaction on micronutrient and heavy metal availabilities has lead some scientists to establish minimum critical values of $\mathrm{pH}$ for soils treated with residues suspected to contain such elements. Mattiazzo-Prezotto (1994) suggested to maintain the $\mathrm{pH}$ $\left(\mathrm{H}_{2} \mathrm{O}\right)$ at the minimum of 5.3 for acid tropical soils, before application of residues containing heavy metals. Higgins (1984) reported that minimum $\mathrm{pH}\left(\mathrm{H}_{2} \mathrm{O}\right)$ values around 6.2 or above, are required to control the phytoavailability of heavy metals and recommended the utilization of low-heavy-metal sewage sludges. In the State of São Paulo, Brazil, the Norm CETESB P4230, which controls the sewage sludge application to soils of the State, establishes that the $\mathrm{pH}\left(\mathrm{CaCl}_{2}\right)$ values ought to be in the range 5.5 to 7.0 , in areas submitted to such sludge treatment (CETESB, 1999). In the present experiments, limed subplots presented values of $\mathrm{pH}$ as high as 6.3 during the year of 1985; however, during most of the period, values of $\mathrm{pH}$ ranged from 5.0 to 6.0 (Table 3). In unlimed subplots, values of $\mathrm{pH}$ stood below 4.5.

\section{Total metal concentrations in the soil}

Total $\mathrm{Cu}$ and $\mathrm{Zn}$ concentrations increased linearly with the increasing doses of sewage sludge, however, the total Ni concentration was not affected (Table 4). Chang et al. (1984) observed that sewage sludge applications, at the rate of $90 \mathrm{Mg} \mathrm{ha}^{-1}$ year $^{-1}$ resulted in heavy metal accumulation in the soil profile, increasing the concentrations of $\mathrm{Cd}, \mathrm{Cr}, \mathrm{Cu}, \mathrm{Ni}$ and $\mathrm{Zn}$, extracted by $4 \mathrm{~mol} \mathrm{~L}^{-1} \mathrm{HNO}_{3}$ solution, from $0.4 ; 19 ; 16 ; 7$ and $110 \mathrm{mg} \mathrm{kg}^{-1}$, determined at the beginning of the experiment, to $8.3 ; 168 ; 146$; 59 e $764 \mathrm{mg} \mathrm{kg}^{-1}$, respectively, in six years. Similar results were reported by Baxter et al. (1983) using the same extractant solution, and by Oliveira (2000) for the $\mathrm{Cu}, \mathrm{Cr}$ and $\mathrm{Zn}$ extracted with aqua regia in microwave oven.

In the present research, the increases observed in total $\mathrm{Cu}$ and $\mathrm{Zn}$ concentrations in the soil samples were correlated to the quantities of these elements added by the sewage sludge (Table 2). However, total Ni concentrations, despite of the high quantities of $\mathrm{Ni}$ added by the sewage sludge applications, remained within the regular range found by Rovers et al. (1983) for soils of the State of São Paulo (<10 a $127 \mathrm{mg} \mathrm{dm}^{-3}$ ) (Table 2). 
Table 3 - Values of $\mathrm{pH}$ in $0.01 \mathrm{~mol} \mathrm{~L} \mathrm{CaCl}_{2}$ in a Rhodic Hapludox soil treated with sewage sludge, in single or split application, with or without liming, during four consecutive years (average of four replications).

\begin{tabular}{|c|c|c|c|c|c|c|c|c|}
\hline \multirow{2}{*}{ Sludge doses } & \multicolumn{2}{|l|}{1984} & \multicolumn{2}{|c|}{1985} & \multicolumn{2}{|l|}{1986} & \multicolumn{2}{|c|}{1987} \\
\hline & $\mathrm{a}$ & $\mathrm{b}$ & $\mathrm{a}$ & $\mathrm{b}$ & $\mathrm{a}$ & $\mathrm{b}$ & $\mathrm{a}$ & $\mathrm{b}$ \\
\hline \multicolumn{9}{|l|}{$\mathrm{Mg} \mathrm{ha}^{-1}$} \\
\hline 0 & 4.8 & 3.9 & 5.1 & 4.1 & 5.9 & 4.1 & 5.6 & 4.1 \\
\hline 20 & 4.6 & 4.0 & 5.4 & 4.1 & 5.3 & 4.1 & 5.6 & 4.0 \\
\hline 40 & 4.8 & 4.0 & 5.4 & 4.4 & 6.0 & 4.4 & 5.5 & 4.1 \\
\hline 60 & 5.2 & 4.0 & 6.3 & 4.3 & 5.6 & 4.4 & 5.2 & 4.2 \\
\hline 80 & 5.2 & 4.2 & 5.0 & 4.4 & 5.8 & 4.4 & 5.2 & 4.3 \\
\hline Regression & $\mathrm{L}^{* *}$ & ns & $\mathrm{Q}^{*}$ & ns & $\mathrm{ns}$ & ns & $\mathrm{ns}$ & ns \\
\hline Liming & $* *$ & & $* *$ & & $* *$ & & $* *$ & \\
\hline C.V. (\%) & 5.6 & & 6.0 & & 5.0 & & 5.5 & \\
\hline $40^{\mathrm{p}}$ & 4.5 & 3.9 & 5.9 & 4.5 & 5.5 & 4.5 & 5.3 & 4.2 \\
\hline $60^{\mathrm{p}}$ & 4.7 & 4.0 & 5.3 & 4.3 & 5.5 & 4.3 & 5.5 & 4.1 \\
\hline $80^{\mathrm{p}}$ & 4.7 & 3.9 & 6.0 & 4.2 & 5.4 & 4.3 & 5.1 & 4.2 \\
\hline
\end{tabular}

a: with liming; b: without liming; L: linear effect; Q: quadratic effect; *,**: significant at 0.05 and 0.01 level, respectively; ns: not significant; ${ }^{\mathrm{p}}$ : total doses of 40,60 and $80 \mathrm{Mg} \mathrm{ha}^{-1}$ of sludge, split in 2, 3 and 4 years, respectively, adding $20 \mathrm{Mg} \mathrm{ha}^{-1}$ year $^{-1}$.

Table 4 - Total $\mathrm{Cu}, \mathrm{Ni}$ and $\mathrm{Zn}$ concentrations in a Rhodic Hapludox soil, treated with sewage sludge, in single or split application (average of eight replications).

\begin{tabular}{lccc}
\hline Sludge & $\mathrm{Cu}$ & $\mathrm{Ni}$ & $\mathrm{Zn}$ \\
\hline $\mathrm{Mg} \mathrm{ha}^{-1}$ & & $\mathrm{mg} \mathrm{dm}^{3}$ & \\
\hline 0 & 1984 & & \\
20 & 50 & 16 & 61 \\
40 & 58 & 20 & 73 \\
60 & 57 & 21 & 76 \\
80 & 61 & 25 & 83 \\
\hline Regression & 70 & 22 & 92 \\
C.V. (\%) & $\mathrm{L}^{* *}$ & $\mathrm{~ns}$ & $\mathrm{~L}^{* *}$ \\
$40^{\mathrm{p}}$ & 7.1 & 9.8 & 10.5 \\
$60^{\mathrm{p}}$ & 59 & 23 & 70 \\
$80^{\mathrm{p}}$ & 55 & 22 & 70 \\
\hline & 56 & 18 & 70 \\
\hline 0 & 1987 & & \\
20 & 56 & 19 & 79 \\
40 & 60 & 23 & 79 \\
\hline 60 & 31 & 20 & 84 \\
80 & 61 & 21 & 88 \\
\hline Regression & 79 & 25 & 123 \\
C.V. (\%) & 13.2 & 12.3 & 22.3 \\
$40^{\text {p }}$ & 64 & 21 & 103 \\
$60^{\text {p }}$ & 73 & 24 & 123 \\
$80^{\text {p }}$ & 76 & 29 & 139 \\
\hline
\end{tabular}

p:total doses of 40, 60 e $80 \mathrm{Mg} \mathrm{ha}^{-1}$ of sludge, split in 2, 3 and 4 years, respectively, adding $20 \mathrm{Mg} \mathrm{ha}^{-1}$ year $^{-1}$; L: linear effect; ***: significant at 0.05 and 0.01 level, respectively; ns: not significant.

\section{Phytoavailability of metals}

DTPA and Mehlich-3 extractant solutions were effective to evaluate availability of $\mathrm{Zn}$ for maize plants, using as reference the $\mathrm{Zn}$ leaf concentration and total $\mathrm{Zn}$ content of shoots (Table 5). For treatments with liming, leaf $\mathrm{Zn}$ concentrations were better correlated to the soil extractable concentrations than to total $\mathrm{Zn}$ content in the shoots, corroborating the results reported by Bataglia \& Raij (1994). On the other hand for, treatments without liming, except for the year of 1986, the total $\mathrm{Zn}$ contents in the shoots presented higher correlation coefficients with the soil concentrations, as compared to leaf $\mathrm{Zn}$ concentrations, for both extractant solutions (Table 5).

Different results were observed for $\mathrm{Cu}$, since high correlation coefficients were only obtained between soil extractable $\mathrm{Cu}$ concentrations and total $\mathrm{Cu}$ contents in the shoots of maize plants, during the four years for the unlimed treatments and during the first year for the limed treatment. When using the variable leaf $\mathrm{Cu}$ concentration to calculate the correlation coefficients, none of the extractants, were effective in evaluating $\mathrm{Cu}$ availability to the maize plants. This might be explained by the fact that there was no effect of increasing sewage sludge doses on the leaf $\mathrm{Cu}$ concentrations, whereas the soil extractable $\mathrm{Cu}$ concentrations, with both extractant solutions, increased linearly in response to the sludge treatments (Figure 1).

Contrarily to the results obtained in this experiment, several authors have reported the superiority of DTPA extractant solution, as compared to acid extractants, in predicting the availability of $\mathrm{Cu}$ (Korcak \& Fanning, 1978; Camargo et al., 1982) and Zn (King \& Hajjar, 1990; Bataglia \& Raij, 1994), and in the ability of DTPA discriminating the effect of $\mathrm{pH}$ increase on the reduction of these metal availabilities. Although the high 
Table 5 - Simple correlation coefficients ( $\mathrm{r}$ ) between $\mathrm{Cu}$ and $\mathrm{Zn}$ leaf concentrations or total shoot contents in maize plants and the soil extractable element concentrations, using DTPA and Mehlich-3 extractant solutions, in soil treated with sewage sludge, in single and split application, with and without liming, during four successive years.

\begin{tabular}{|c|c|c|c|c|c|c|c|c|}
\hline \multirow{3}{*}{$\begin{array}{l}\text { Extractant } \\
\text { solutions }\end{array}$} & \multicolumn{8}{|c|}{ Correlation coefficients } \\
\hline & \multicolumn{4}{|c|}{ Leaf metal concentration } & \multicolumn{4}{|c|}{ Absorbed quantitie } \\
\hline & 1984 & 1985 & 1986 & 1987 & 1984 & 1985 & 1986 & 1987 \\
\hline & \multicolumn{8}{|c|}{ With liming } \\
\hline & \multicolumn{8}{|c|}{$\mathrm{Cu}$} \\
\hline DTPA & 0.192 & -0.022 & 0.217 & 0.238 & $0.595 * *$ & $0.351 *$ & 0.011 & 0.012 \\
\hline \multirow[t]{2}{*}{ Mehlich-3 } & 0.198 & -0.063 & 0.21 & 0.305 & $0.669 * *$ & 0.164 & 0.201 & 0.001 \\
\hline & \multicolumn{8}{|c|}{$\mathrm{Zn}$} \\
\hline DTPA & $0.779 * *$ & $0.547 * *$ & $0.602 * *$ & $0.572 * *$ & $0.868 * *$ & 0.246 & 0.236 & $0.620 * *$ \\
\hline \multirow[t]{3}{*}{ Mehlich-3 } & $0.729 * *$ & $0.502 * *$ & $0.560 * *$ & $0.534 * *$ & $0.860 * *$ & 0.21 & 0.255 & $0.493 * *$ \\
\hline & \multicolumn{8}{|c|}{ Without liming } \\
\hline & \multicolumn{8}{|c|}{$\mathrm{Cu}$} \\
\hline DTPA & 0.089 & 0.056 & 0.168 & 0.225 & $0.741 * *$ & $0.570 * *$ & $0.458 * *$ & $0.442 *$ \\
\hline \multirow[t]{2}{*}{ Mehlich-3 } & 0.015 & 0.229 & 0.278 & 0.151 & $0.682 * *$ & $0.479 * *$ & $0.571 * *$ & $0.509 * *$ \\
\hline & \multicolumn{8}{|c|}{$\mathrm{Zn}$} \\
\hline DTPA & $0.707 * *$ & $0.622 * *$ & $0.763 * *$ & $0.797 * *$ & $0.750 * *$ & $0.653 * *$ & $0.536 * *$ & $0.882 * *$ \\
\hline Mehlich-3 & $0.689 * *$ & $0.565 * *$ & $0.808 * *$ & $0.758 * *$ & $0.723 * *$ & $0.620 * *$ & $0.638 * *$ & $0.894 * *$ \\
\hline
\end{tabular}

*,**: significant at 0.05 and 0.01 level, respectively.

Ni concentrations found in sewage sludge samples (Table1) and the increasing soil extractable Ni concentrations found in the soil samples from plots treated with increasing sludge doses (Figura 1), Ni was not detected in the analyzed plant parts (leaves, shoots and grains).

\section{ACKNOWLEDGEMENTS}

To FAPESP and CNPq for financial support and fellowships.

\section{REFERENCES}

ABREU, C.A; ABREU, M.F.; RAIJ, B. van.; SANTOS, W.R. Comparação de métodos de análise para avaliar a disponibilidade de metais pesados em solos. Revista Brasileira de Ciência do Solo, v.19, p.463-468, 1995.

ABREU, M.F.; BERTON, R.S.; ANDRADE, J.C. Comparison of methods to evaluate heavy metals in organic wastes. Communications in Soil Science and Plant Analysis, v.27, p.1125-1135, 1996.

ANJOS, A.R.M. \& MATTIAZZO, M.E. Extratores para $\mathrm{Cd}, \mathrm{Cu}, \mathrm{Cr}, \mathrm{Mn}$, $\mathrm{Ni}, \mathrm{Pb}$ e $\mathrm{Zn}$ em Latossolos tratados com biossólidos e cultivados com milho. Scientia Agricola, v.58, p.337-344, 2001.

BATAGLIA, O.C.; RAIJ, B. van. Soluções extratoras na avaliação da fitodisponibilidade do zinco em solos. Revista Brasileira de Ciência do Solo, v.18, p.457-461, 1994.

BATAGLIA, O.C.; TEIXEIRA, J.P.F.; FURLANI, P.R.; FURLANI, A.M.C.; GALLO, J.R. Métodos de análise química de plantas. Campinas: Instituto Agronômico, 1978. 31p. (Circular, 87).

BAXTER, J.C.; AGUILAR, M.; BROWN, K. Heavy metals and persistent organics at a sewage sludge disposal site. Journal of Environmental Quality, v.12, p.311-316, 1983.

BERTON, R.S.; VALADARES, J.M.A.S.; CAMARGO, O.A.; BATAGLIA, O.C. Peletização do lodo de esgoto e adição de $\mathrm{CaCO}_{3}$ na produção de matéria seca e absorção de $\mathrm{Zn}, \mathrm{Cu}$ e Ni pelo milho em três latossolos. Revista Brasileira de Ciência do Solo, v.21, p.685-691, 1997.
BIDWELL, A.M.; DOWDY, R.H. Cadmium and zinc availability to corn following termination of sewage sludge applications. Journal of Environmental Quality, v.16, p.438-442, 1987.

CAMARGO, O.A.; MONIZ, A.C.; JORGE, J.A.; VALADARES, J.M.A.S Métodos de análise química, mineralógica e física de solos do Instituto Agronômico de Campinas. Campinas: Instituto Agronômico, 1986. 94p. (Boletim Técnico, 106).

CAMARGO, O.A.; ROVERS, H.; VALADARES, J.M.A.S. Adsorção de níquel em latossolos paulistas. Revista Brasileira de Ciência do Solo, v.13, p.125-129, 1989.

CAMARGO, O.A.; VALADARES, J.M.A.S.; DECHEN, A.R. Efeitos do $\mathrm{pH}$ e da incubação na extração do manganês, zinco, cobre e ferro do solo. Revista Brasileira de Ciência do Solo, v.6, p.83-88, 1982.

CAVALlARO, N.; PADILlA, N.; VILLARRUBIA, J. Sewage sludge effects on chemical properties of acid soils. Soil Science, v.156, p.6370, 1993.

CHANEY, R.L.; GIORDANO, P.M. Microelements as related to plant deficiencies and toxicities. In: ELLIOTT, L.F.; STEVENSON, F.J. (Ed.) Soils for management of organic wastes and wastewaters. Madison: SSSA, 1977. p.234-279.

CHANG, A.C.; WARNEKE, J.E.; PAGE, A.L.; LUND, L.J. Accumulation of heavy metals in sewage sludge-treated soils. Journal of Environmental Quality, v.13, p.87-91, 1984.

COMPANHIA DE TECNOLOGIA E SANEAMENTO AMBIENTAL CETESB. Aplicação de lodos de sistemas de tratamento biológico em áreas agrícolas - critérios para projeto e operação. São Paulo: CETESB, 1999. 32p. (Manual Técnico, P 4230)

DOWDY, R.H.; LARSON, W.E. The availability of sludge-borne metals to various vegetable crops. Journal of Environmental Quality, v.4, p.278282, 1975.

HAQ, A.U.; BATES, T.E.; SOON, Y.K. Comparison of extractants for plantavailable zinc, cadmium, nickel and copper in contamined soils. Soil Science Society of America Journal, v.44, p.772-777, 1980.

HECKMAN, J.R.; ANGLE, J.S.; CHANEY, R. L. Residual effects of sewage sludge on soybean: I. Accumulation of heavy metals. Journal of Environmental Quality, v.16, p.113-117, 1987.

HIGGINS, A.J. Land application of sewage sludge with regard to cropping systems and pollution potential. Journal of Environmental Quality, v.13, p.441-448, 1984. 
JEFFERY, J.J.; UREN, U.C. Copper and zinc species in the soil solution and the effects of soil pH. Australian Journal of Soil Science, v.21, p.479-488, 1983.

KING, L.D.; HAJJAR, L.M. The residual effect of sewage sludge on heavy metal content of tobacco and peanut. Journal of Environmental Quality, v.19, p.738-748, 1990.

KORCAK, R.F.; FANNING, D.S. Extractability of cadmium, copper, nickel and zinc by double acid versus DTPA and plant content at excessive soil levels. Journal of Environmental Quality, v.7, p.506-512, 1978.

KORCAK, R.F.; FANNING, D.S. Availability of applied heavy metals as a function of type of soil material and metal source. Soil Science, v.140, p.23-34, 1985.

KREBS, R.; GUPTA, S.K.; FURRER, G.; SCHULIN, R. Solubility and plant uptake of metals with and without liming of sludge-amended soils Journal of Environmental Quality, v.27, p.18-23, 1998.

LATTERELL, J.J.; DOWDY, R.H.; LARSON, W.E. Correlation of extractable metals and metal uptake of snap beans grown on soil amended with sewage sludge. Journal of Environmental Quality, v.7, p.435440, 1978

LINDSAY, W.L.; NORVELL, W.A. Development of a DTPA soil test for zinc, iron, manganese and copper. Soil Science Society of America Journal, v.42, p.421-428, 1978.

LOGAN, T.J.; CHANEY, R. Metals. In: PAGE, A.L.; GLEASON, T.L.; SMITH, J.E.; ISKANDAR, J.K.; SOMMERS, L.E. (Ed.) Utilization of municipal wastewater and sludge on land. Riverside: University of California, 1983. p.235-326.

LUO, Y.M.; CHRISTIE, P. Bioavailability of copper and zinc in soils treated with alkaline stabilized sewage sludge. Journal of Environmental Quality, v.27, p.335-342, 1998.

MATTIAZZO-PREZOTTO, M.E. Comportamento de cobre, cádmio, cromo, níquel e zinco adicionados a solos de clima tropical em diferentes valores de pH. Piracicaba: USP/ESALQ, 1994. 197p. (Tese - Livre-Docência)

McBRIDE, M.B. Reactions controlling heavy metal solubility in soils. Advances in Soil Science, v.10, p.1-57, 1989.

McBRIDE, M.B. Toxic metal accumulation from agricultural use of sludge: are USEPA regulations protective? Journal of Environmental Quality, v.24, p.5-18, 1995.

McGRATH, S.P.; CEGARRA, J. Chemical extractability of heavy metals during and after long-term applications of sludge to soil. Journal of Soil Science, v.43, p.313-321, 1992.

MEHLICH, A. Mehlich 3 soil test extractant: a modification of Mehlich 2 extractant. Communications in Soil Science and Plant Analysis, v.15, p.1409-1416, 1984.
OLIVEIRA, F.C. Disposição de lodo de esgoto e composto de lixo urbano num latossolo vermelho-amarelo cultivado com cana-de-açúcar. Piracicaba: USP/ESALQ, 2000. 237p. (Tese - Doutorado)

OLIVEIRA, F.C; MATTIAZZO, M.E. Metais pesados em Latossolo tratado com lodo d esgoto e em plantas de cana-de-açúcar. Scientia Agricola v.58, p.581-593, 2001

POMBO, L.; SALGADO, V.; VOLKWEISS, S.; KLAMT, E. Adsorção de níquel por dois solos: terra bruna estruturada similar e podzólico vermelho-amarelo. Pesquisa Agropecuária Brasileira, v.24, p.593-598, 1989

RAIJ, B. van; QUAGGIO, J.A. Métodos de análise de solo para fins de fertilidade. Campinas: Instituto Agronômico, 1983. 31p. (Boletim Técnico, 81).

RAPPAPORT, B.D.; MARTENS, D.C.; RENEAU JUNIOR, R.B.; SIMPSON, T.W. Metal availability in sludge-amended soils with elevated metal levels. Journal of Environmental Quality, v.17, p.42-47, 1988.

ROVERS, H.; CAMARGO, O.A.; VALADARES, J.M.A.S. Níquel total e solúvel em DTPA em solos do Estado de São Paulo. Revista Brasileira de Ciência do Solo, v.7, p.217-220, 1983.

SIMONETE, M.A. \& KIEHL, J.C. Extração e fitodisponibilidade de metais e resposta à adição de lodo de esgoto no solo. Scientia Agricola, v.59, p.555-563, 2002

SIMS, J.T.; KLINE, J.S. Chemical fractionation and plant uptake of heavy metals in soils amended with co-composted sewage sludge. Journal of Environmental Quality, v.20, p.387-395, 1991

SINGH, B.R.; NARWAL, R.P. Plant availability of heavy metals in a sludgetreated soil: II. Metal extractability compared with plant metal uptake. Journal of Environmental Quality, v.13, p.344-349, 1984.

VALADARES, J.M.A.S.; GAL, M.; MINDELGRIN, U.; PAGE, A.L. Some heavy metals in soils treated with sewage sludge, their effects on yield and their uptake by plants. Journal of Environmental Quality, v.12, p.49-57, 1983.

WILLIAMS, D.E.; VLAMIS, J.; PUKITE, A.H.; COREY, J.E. Trace element accumulation, movement, and distribution in the soil profile from massive applications of sewage sludge. Soil Science, v.129, p.119$132,1980$.

Received August 12, 2002

Accepted August 12, 2003 